\title{
A modified protocol of the alloxan technique for the induction of diabetes mellitus in Wistar rats
}

\author{
[Protocolo modificado de indução à diabetes mellitus por aloxana em ratos Wistar]
}

"Short Communication/Comunicação Breve"

\author{
Renato de Souza Abboud ${ }^{1}$, Mauricio Alves Chagas ${ }^{1 *}$, Ilma Cely de Amorim Ribeiro ${ }^{1}$, Lanna \\ Beatriz Neves Silva Corrêa ${ }^{1}$, Raquel Milhomem Lange ${ }^{2}$
}

\author{
${ }^{1}$ Universidade Federal Fluminense, Niterói-RS, Brasil. \\ ${ }^{2}$ Universidade Castelo Branco, Rio de Janeiro-RJ, Brasil. \\ *Autor para correspondência/Corresponding author: E-mail: chagas_m@vm.uff.br
}

\begin{abstract}
The chemical induction of diabetes mellitus in Wistar rats using alloxan is a commonly adopted scientific method for obtaining experimental models. Although a wide variety of induction protocols have been reported, no standard protocol has been defined due to high mortality rates, reversal, and failure of induction. Therefore, this study proposes an adaptation of the technique to induct diabetes mellitus through a 30-hour fast and a $150 \mathrm{mg} / \mathrm{kg}$ dosage of alloxan. The proposed technique has proved to be highly effective.
\end{abstract}

Keywords: chemical induction; experimental diabetes; hyperglycemia; alloxan protocol.

\section{Resumo}

A indução química ao diabetes mellitus em ratos Wistar usando aloxana é um método científico usualmente utilizado para a obtenção de modelos experimentais. Grande variedade de protocolos de indução são reportados na literatura, no entanto, não há um protocolo padrão adotado devido às altas taxas de mortalidade, reversibilidade e falha na indução. Portanto, este estudo propõe uma adaptação da técnica de indução ao diabetes, adotando um jejum de 30 horas e uma dosagem de $150 \mathrm{mg} / \mathrm{kg}$ a fim de obter alta eficiência.

Palavras-chave: hiperglicemia; diabetes experimental; indução química; protocolo de aloxana.

The chemical induction of diabetes mellitus in Wistar rats by using cytotoxic drugs to produce experimental animal models is still widely practiced (Zanoello et al., 2002; Ribeiro et al., 2007). The diabetogenic properties of alloxan have been studied since 1943 when Dunn et al. (1943) examined the effect of its administration on rabbits and reported specific necrosis in the pancreatic islets. However, there is no standard protocol for the induction of diabetes, and the existing techniques present high mortality rates, reversion, and failure of induction due to the chemical instability of the drug. Rapid metabolism and factors such as diet, weight, and age, make it difficult to establish the dosage of alloxan that would be most effective in the pancreas (Federiuk et al., 2004; Negri, 2005; Ribeiro et al., 2007).

The application of alloxan intravenously/intraperitoneally selectively destroys pancreatic $\beta$ cells since its molecule is similar to a glucose molecule as it is captured by the glucose transporter GLUT2, which is present in the plasma of the $\beta$-cell membrane, and it is transported to the cytosol, thereby promoting a massive release of insulin (Szkudelski et al., 1998; Lima et al., 2001; Szkudelski, 2001).

Through a redox reaction, alloxan begins to produce a reactive oxygen species (free radicals), thus initiating toxic damage to $\beta$-cells (Lenzen, 2008). The action of alloxan on $\beta$ cells is initiated when the hydroxyl radicals affect the oxidative 
metabolism of the cells with subsequent selective necrosis of the $\beta$ cells and cell deaths, which causes a state of insulin-dependent diabetes (Zanoello et al., 2002; Lenzen, 2008). $\beta$-cells exhibit a higher sensitivity to peroxide radicals when compared to other tissues because of the low activity of GSH peroxidase, which catalyzes the reduction of peroxides in these cells (Lima et al., 2001; Szkudelski, 2001; Cavalli et al., 2007).

Different animal species can be used as models of diabetes mellitus after being induced with alloxan, including rats, dogs, rabbits, hamsters, guinea pigs, and even sheep (Lerco et al., 2003; Federiuk et al., 2004).

Young (55-day old) male Wistar Furth rats provided by the Laboratory Animal Center (NAL/UFF), were used for the induction of diabetes. These animals were housed in individual cages in a controlled environment with respect to temperature, humidity, and noise, and they were fed pelleted commercial feed (Nuvilabß) ad libitum. The induction process was initiated with a 30-hour feed restriction for the animals, during which the animals received no food but received water at will. After the fasting period, the animals were manually restrained and received an intraperitoneal injection of monohydrate alloxan, + 98\% (Cayman Chemical, code 9002196), which was previously diluted in a solution of $0.9 \%$ sodium chloride (at a ratio of $600 \mathrm{mg}$ of alloxan in $40 \mathrm{~mL}$ of the saline solution). From this solution, at $1.5 \%$, a volume of $1 \mathrm{~mL}$ per 100 grams of live weight was applied with a $25 \times 6$ needle in the lower right abdominal quadrant after the animal was properly contained. Subsequently, the rats were re-housed in their cages with water and commercial feed ad libitum.

The glycemia of all the rats was measured 3 days after the administration of alloxan, after establishing a 6-hour fast. One drop of blood was withdrawn by puncturing the tail of the animals with the aid of a stylus and by using a OneTouch Ultra blood glucose meter (Johnson \& Johnson Company, USA) to analyze the glycemia of the animals. All the animals that presented glycemic levels equal to or greater than $270 \mathrm{mg} / \mathrm{dl}$ were considered to be diabetic and included in the experiment (Moustafa et al., 2004). The experimentation on the animals in the animal facility continued for 60 days, during which the glycemic levels, food intake, and body weight evolution of all the animals were evaluated. No animals died after induction or during the subsequent period of experimentation. No cases of reversal were observed.

In the induction protocols, intravenous (iv) alloxan is often administered to rats at a dose of 40 to $65 \mathrm{mg} / \mathrm{kg}$ (Szkudelski, 2001; Carvalho et al., 2003; Lerco et al., 2003; Cavalli et al., 2007). However, when administered intraperitoneally or subcutaneously, the effective dose is usually two to three times higher (Szkudelski, 2001).

The analysis of glycemia was used to control the efficiency of alloxan in the destruction of the $\beta$ cells of the pancreas.

The administration of alloxan caused an increase in blood glucose levels in the first week following the application of the drug, and this increase was maintained over 8 weeks (Figure 1). The findings of this study show the effectiveness of the $150 \mathrm{mg} / \mathrm{kg}$ dose administered intraperitoneally to rats. There was no mortality after induction, and $100 \%$ of the animals became diabetic.

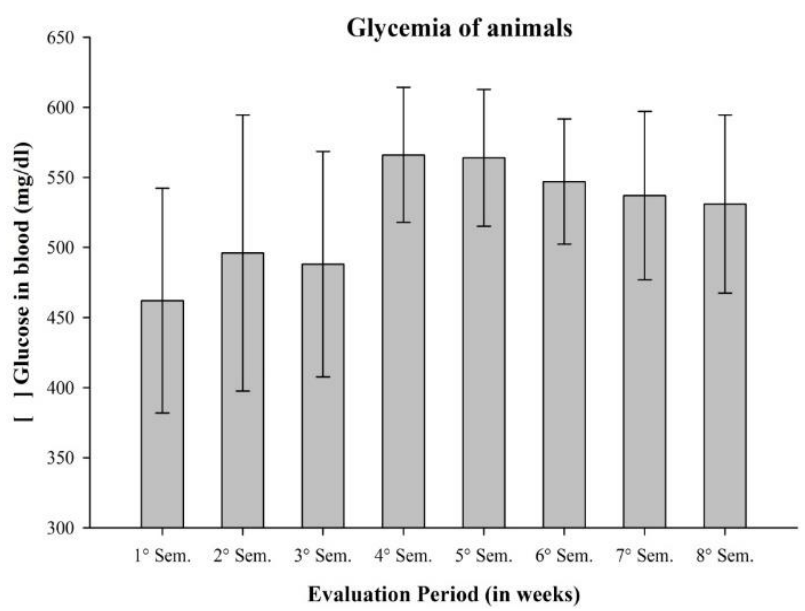

Figure 1. Evolution of blood glucose levels after induction with alloxan. Note that the levels remain high until the end of the experiment.

Szkudelski (2001), in his study, demonstrated that an intraperitoneal dose below $150 \mathrm{mg} / \mathrm{kg}$ might be insufficient to induce diabetes in rats, thereby raising the requirement of a second dose. Silva et al. (2014) reported that a dose of $200 \mathrm{mg} / \mathrm{kg}$ administered intraperitoneally results in a high percentage of diabetic animals. However, it causes a higher mortality rate when compared to doses lower than $80 \mathrm{mg} / \mathrm{kg}$ and 120 $\mathrm{mg} / \mathrm{kg}$. Federiuk et al. (2004) studied several protocols of diabetes induction and found that a dose of $200 \mathrm{mg} / \mathrm{kg}$ of alloxan administered 
intraperitoneally in a group of 10 animals with diabetes killed one animal during the first week. In the present study, the $150 \mathrm{mg} / \mathrm{kg}$ dose at a $1.5 \%$ dilution was administered intraperitoneally with a 30-hour fast. It effectively led to an increase in the glycemic characteristic of the disease in several animals without post-induction deaths and reversion. The efficacy of alloxan is directly proportional to the time taken for the fast (Zanoello et al., 2002; Lerco et al., 2003; Federiuk et al., 2004; Cavalli et al., 2007). In a study by Silva and Nogueira (2015), a 24-hour fast along with a dose of $150 \mathrm{mg} / \mathrm{kg}$ of alloxan proved a reduction in the number of diabetic animals - $\mathrm{a}$ reversal had occurred. The animals had become hyperglycemic on the 7th day and normoglycemic on the 14th day. The production of animal models for the study of metabolic diseases is essential for the development of new therapies. The refinement of the diabetes induction technique reported in this study has greatly increased the efficiency of the method by reducing the failure and mortality rates. Therefore, researchers can safely decrease the use of animals in their experiments and contribute to future studies and the development of new drugs in accordance with two of the items included in the humanitarian principles of animal experimentation: reduction and refinement.

\section{Conflict of interest}

The authors declare no conflict of interest.

\section{Ethics Committee}

The research Project was approved by the ethics committee of the Federal Fluminense University, under number 972.

\section{Acknowledgments}

This work was supported by the Fundação de Amparo à Pesquisa do Estado do Rio de Janeiro (FAPERJ).

\section{References}

Carvalho, E.N.; Carvalho, N.A.S.; Ferreira, L.M. Experimental model of induction of diabetes mellitus in rats. Acta Cirurgica Brasileira, 18: 60-64, 2003.

Cavalli, V.L.; Sordi, C.; Tonini, K.; Grando, A.; Muneron, T.; Guigi, A.; Roman Júnior, W.A. Avaliação in vivo do efeito hipoglicemiante de extratos obtidos da raiz e folha de bardana Arctium minus (Hill). Revista Brasileira de Farmacognosia, 17(1): 64-70, 2007.
Dunn, J.S.; Sheehan, H.L.; Mclethie, N.G.B. Necrosis of islets of Langerhans produced experimentally. The Lancet, 1: 484-487, 1943.

Federiuk, I.F.; Casey, H.M.; Quinn, M.J.; Wood, M.D.; Ward, W.K. Induction of type-1 Diabetes mellitus in laboratory rats by use of alloxan: route of administration, pitfalls, and insulin treatment. Comparative Medicine, 54(3): 252-257, 2004.

Lenzen, S. The mechanisms of alloxan- and streptozotocin-induced Diabetes. Diabetologia, 51(2): 216-226, 2008.

Lerco, M.M.; Spadella, C.T.; Machado, J.L.M.; Schellini, S.A.; Padovani, C.R. Caracterização de um modelo experimental de Diabetes mellitus, induzido por aloxana em ratos. estudo clínico e laboratorial. Acta Cirurgica Brasileira, 18(2): 132-142, 2003.

Lima, M.A.; Lima, L.M.B.; Rita, D.P.C.; Navarro, F.C.; Tatsukawa, R.S.; Pereira, G.A.; Reis, L.C.; Abreu, M.E.A.; Borges, M.F. Análise quantitativa das células das ilhotas pancreáticas em ratos sob efeito de aloxana. Medicina (Ribeirão Preto), 34(1): 308-314, 2001.

Moustafa, M.H.; Sharma, R.K.; Thornton, J.; Mascha, E.; Abdel-Hafez, M.A.; Thomas, A.J. Jr.; Agarwal, A. Relationship between ROS production, apoptosis and DNA denaturation in spermatozoa from patients examined for infertility. Human Reproduction, 19(1): 129138, 2004.

Negri, G. Diabetes melito: plantas e princípios ativos naturais hipoglicemiantes. Revista Brasileira de Ciências Farmacêuticas, 41(2): 121-42, 2005.

Ribeiro, C.; Oliveira, C.A.M.; Mello, M.A.R. Exercício e prevenção do Diabetes mellitus: importância do modelo experimental utilizando ratos. Motriz, 13(1): 72-77, 2007.

Silva, V.D.; Nogueira, R.M.B.; Oliveira, G.I.V.; Giuffrida, R. Comparison of induction of Diabetes mellitus with alloxan in different doses in Wistar rats. Semina: Ciências Agrárias, 35(4): 2463-2470, 2014.

Silva, V.D.; Nogueira, R.M.B. Diabetes mellitus experimental induzido com aloxana em ratos Wistar. Revista de Ciências Farmacêuticas Básica e Aplicada, 36(1): 9-15, 2015.

Szkudelski, T.; Kandulska, K.; Okulicz, M. Alloxan in vivo does not only exert deleterious effects on pancreatic B cells. Physiological Research, 47(5): 343-6, 1998. 
Szkudelski, T. The mechanism of alloxan and streptozotocin action in B cells of the rat pancreas. Physiological Research, 50: 536546, 2001.

Zanoello, A.M.; Mazzanti, C.M.; Gindri, J.K.;

Filappi, A.; Prestes, D.; Cecim, M. Efeito
Protetor do Syzygiumcumini contra Diabetes mellitus induzido por aloxano em ratos. Acta Farmaceutica Bonaerense, 21(1): 31-36, 2002. 